\title{
Testing Leverage and Spillover Effects in Precious Metal ETFs
}

\author{
Jo-Hui Chen"1, Thi Van Trang Do \\ ${ }^{1}$ Department of Finance, Chung Yuan Christian University, Chung-li, Taiwan \\ ${ }^{2}$ Department of Finance, Banking Academy, Hanoi, Vietnam \\ Email: johui@cycu.edu.tw, tranhabach@yahoo.com
}

How to cite this paper: Chen, J.-H. and Do, T.V.T. (2018) Testing Leverage and Spillover Effects in Precious Metal ETFs. Theoretical Economics Letters, 8, 197-212. https://doi.org/10.4236/tel.2018.83015

Received: November 20, 2017

Accepted: February 6, 2018

Published: February 9, 2018

Copyright (c) 2018 by author s and Scientific Research Publishing Inc. This work is licensed under the Creative Commons Attribution International License (CC BY 4.0).

http://creativecommons.org/licenses/by/4.0/

\begin{abstract}
This research employed the Generalized Autoregressive Conditional Heteroskedasticity-in-Mean-Autoregressive Moving Average (GARCH-M-ARMA) and the Exponentially Generalized Autoregressive Conditional Heteroskedasticity-in-Mean-Autoregressive Moving Average (EGARCH-M-ARMA) models to investigate the spillover and leverage effects in the returns and volatilities of precious metal (base metal) ETFs. Significant positive relationships were found between precious metal (base metal) ETFs and precious metal (base metal) price indices. Further, the positive relationship between risk and return was illustrated in daily precious metal (base metal) ETFs.
\end{abstract}

\section{Keywords}

Precious Metal ETFs, Spillover Effect, Leverage Effect

\section{Introduction}

Exchange-traded funds (ETFs) are known as financial innovations that have demonstrated tremendous international growth since ETFs were being initially introduced in 1993. ETFs are traded similarly as shares of stock on public security exchanges [1]. The ETF index is generated as an investment trust, and new shares are created when an institutional investor deposits securities into the trust. The regulation for ETFs indicates that securities can be created and redeemed only on the fund's net asset value at the end of the trading day. When the efficiency of the electronic trading platform rises, a competitive environment arises and downward pressure is exerted on bid-ask spreads. Such a scenario induces an increase in the uncertainty of exposure from order imbalances. If fund managers do not practice any methods of hedging in declining markets, inves- 
tors should be prepared to bear the risks of loss and volatility associated with underlying securities. As in other securities or assets, investors have to bear the market risk or volatility of the specific underlying securities, which the ETF tracks. When the market is under an economic crisis or unstable condition such that stock, bond, or commodity prices decrease, the value of ETFs would also decline.

In the literature concerning different categories of ETFs, many authors have concentrated on the characteristics of different kinds of ETFs. Leveraged ETFs have larger volatility than traditional ETFs [2]. Price deviations present differently between bull and bear ETFs. For example, bull ETFs trade at a discount or at a slight premium to their net asset values, whereas bear ETFs trade at a larger premium. The premiums of bull (bear) ETFs show different reactions with the returns on their own benchmarks such as negative (positive) correlations. Chen [3] gathered data on returns of volatilities and leverage effects for both ethical and non-ethical ETFs against benchmark indices, and estimated the spillover effect after negative ethical screening was applied on ETFs. The current stock index returns are influenced by the lagged ethical ETF returns, and a bilateral relationship exists between them. Blitz and Huij [4] compared the performance of emerging markets ETFs to developed markets ETFs. The authors found that emerging markets ETFs have higher levels of tracking error than developed markets ETFs, suggesting that emerging markets ETFs have higher cross-sectional dispersion in stock returns.

Precious metals are known as metals that are scarce and naturally occurring metallic elements with high economic value. They are also considered an investment hedge against risk when the economy is unstable or has a financial crisis. Precious metals maintain their stored value function and are effective investment tools. They can also be utilized for practical usages. Thus, the demand for precious metals has increased significantly. This phenomenon has caused the volatilities in the prices of these types of metals to be remarkably attractive in recent years. In addition, with the development of sophisticated technology in many manufacturing fields, precious metals are now considered important materials. Some of these precious metals are unique and non-substitutable materials, and producers have to trade them at high prices, especially when the market has large volatility. Moreover, there are hundreds of tracked or benchmarked indices that are categorized by mutual funds and ETFs based on different criteria, such as bond/fixed income, commodity, currency, diversified portfolio, equity, inverse, leveraged, and real estate indices. However, to date, no empirical study has focused on precious metals and base metals ETFs. Furthermore, investment in precious metals (base metals) ETFs may be a reasonable approach when investors consider diversifying their investment portfolios. Therefore, the aim of this research is to concentrate on precious metal ETFs in different approaches and make comparisons with base metal ETFs to represent the differences between the distinguished metal ETFs. 
The GARCH model was developed by Bollerslev et al. [5] and is considered the most appropriate model to fit the feature of ETFs and precious metal indices. Since these models have high peakedness and fat tails compared with a normal distribution, they allow for time varying conditional correlation of these stock markets [6]. Furthermore, the advantage of these models represents the ability to model the dynamic behavior of financial investment tools. By using the GARCH approach, there are many studies mentioned on unilateral and bilateral return influences and leverage effects. These studies include Wei et al. [7], Bhar and Nikolova [6], and Korkmaz et al. [8] studied about stocks. Chan et al. [9] and Zhong et al. [10], Kanas [11] and Zhang et al. [12] examined futures and commodities. Therefore, this section presents the empirical evidence that ETFs and their precious metal indices represent unilateral or bilateral influence through positive and negative effects on each other.

Previous empirical research has not yet mentioned the interdependence of precious metal ETFs and precious metal indices. Consequently, the purpose of this study is to explore the spillover and leverage effects from the returns and volatilities of precious metal ETFs and precious metal indices and vice versa. This study utilized both the generalize autoregressive conditional heterokadasticity in mean (GARCH-M)-autoregressive moving average (ARMA) models and the exponentially generalized autoregressive conditional heterokadasticity in mean (EGARCH-M)-autoregressive moving average (ARMA) models. The motivation for examining volatility spillovers is as followed. First, in recent decades, the precious metal prices have increased sharply, especially the price of gold. The demand for precious metals for manufacturing has increasingly gone up as these rare metals have become scarce. On the contrary, precious metal ETFs presented unstable trends in volatility. This leads to some degree of interdependence between precious metal ETFs and precious metal indices. Hence, investors may recognize the signal of market trends that influence allocations of investors throughout transmission effects. Second, positive and significant spillover effects of volatility might raise the nonsystematic residual portfolio faced by investors. Thus, the findings of spillover of returns, volatilities, and leverage effects play an important part for investors and fund managers to reduce the gains from portfolio diversification. Third, an understanding of the linkages between the volatility of precious metal ETFs and precious metal indices may help investors hedge and manage both precious metal ETF and precious metal index exposures. Finally, no empirical study has concentrated on these interdependences, hence this is the first approach that highlights the linkages between the volatility of precious metal ETFs and precious metal indices. Our findings provide valuable information to the investing community on creating market perspectives and excess returns.

The main results of this paper are presented as follows. This paper has demonstrated that all precious metal (base metal) ETFs have exhibited strong evidence of volatility asymmetry. The paper has detected the significant positive effects of lagged precious metal (base metal) price returns on current precious metal (base metal) ETF returns and vice versa. The evidence of positive unilater- 
al relationship in returns is presented by iShares Silver Trust (SLV), ETFS Physical Palladium Shares (PALL), and iPath DJ-UBS Copper TR Sub-Idx ETN (JJC), while other precious metal (base metal) performed a bilateral positive relationship with current price returns. Furthermore, the positive relationship has proven that return and risk gained in precious metal (base metal) ETFs can emanate from the increase (decrease) of the others. The evidences of spillover and leverage effects of precious metal (base metal) ETFs might be obvious signs for investors, traders, speculators, and fund managers when making decisions.

This paper is designed as follows. Section 2 mentions the review of literature. Section 3 explains the data and methodology of GARCH-M-ARMA and EGARCH-M-ARMA. Section 4 represents the empirical results. Section 5 concludes this study.

\section{Literature Review}

The topics of interdependence of financial markets have received great attention in financial literature, especially for augmented return and volatility spillover effects. The application of spillover effect was implemented by researchers in different kinds of financial variables, such as commodities, exchange rate, bonds, futures, and options, particularly in stocks and ETFs. The research of spillover and leverage effects between different markets has been discussed. Kanas [11] focused on the volatility spillover across stock returns and exchange rate changes in six countries. These relationships have become stronger since the stock market crash in 1987. Zhang et al. [12] have shown three spillover effects such as mean spillover, volatility spillover, and risk spillover between the US dollar and international crude oil prices. A strong long-term equilibrium cointegrating relationship was detected between the two markets. Moreover, the apparent volatility and clustering between the two markets were also significantly indicated.

Regarding the spillover effects between stock markets and futures markets, Chan et al. [9] showed a significant intermarket dependence in the volatility of $\mathrm{S}$ \&P 500 stock index and stock index futures markets. As for the approach of modified EGARCH models, Zhong et al. [10] estimated the spot market and futures market of the Mexican stock index for spillover effects. Thus, futures price was proved a useful discovery instrument.

The transmission volatility across stock markets has been examined in recent studies by Wei et al. [7]. They examined the volatility and price change spillover effects across developed and emerging markets. Interesting evidence proved that the New York market presented stronger influence than the Tokyo market over the Taiwan and Hong Kong markets; the Taiwan market performed more sensitively to developed markets over Hong Kong markets. Bhar and Nikolova [6] looked at the different levels of integration among Brazil, Russia, India, and China (BRIC) across their regions and the world in the post-liberalization period through bivariate EGARCH models. They found that India has exhibited the highest integration of its stock index to the world and was followed by Brazil, Russia, and China. Korkmaz et al. [8] observed the low contemporaneous return 
and volatility spillover effects in six emerging markets, and these stock markets represented a higher degree of co-movement relationship.

For literature concerned with spillover effects, we continue to apply other financial variables, such as ETFs, that were close references to our study. Kim [13] detected the difference between the periods before and after the global financial crisis in cointegration and spillover effects between U.S. and Asian-Pacific ETF markets. The U.S. stock market has still maintained its position as the major driver in Asia-Pacific stock markets through the strong spillover effect of shock and volatility among these ETF markets. Krause and Tse [14] observed volatility and return spillovers in Canadian and U.S. industry ETFs to address the price discovery flows from the U.S. to Canada for industry ETFs. Negative returns play a major role in the return-creating process, and asymmetric volatility is given in all U.S. volatility spillovers, appearing bi-directionally in financial and technology sectors. Likewise, basic materials and energy sectors of the U.S. to Canada also reveal bi-directionally pattern. Curcio et al. [15] revealed that real estate ETFs affected the volatility of their underlying real estate stocks. The evidence showed a significant increase in the volatility of their component real estate ETFs. The high volatility was the leveraged ETFs to the Dow Jones US real estate and financial Indices, followed by traditional ETFs. The last was the linkage between leveraged ETFs and the Russell 1000 financial services index.

Empirical research has been used in other studies such as Chen and Huang [16]. They carried out a multiple GARCH-ARMA and EGARCH-ARMA to recognize the spillover and leverage effects of both returns and volatilities when analyzing the relation between stock indices and ETFs in nine stock markets. The authors showed evidence that bilateral effects and asymmetry volatilities exist between the stock indices and ETFs for developed markets as well as emerging markets. With a similar approach, Chen [3] considered five ethical ETFs and compared them with other five non-ethical ETFs to observe a different period of times to detect the spillover and leverage effects between them. The author proved that the lagged ethical ETF returns affected the current stock index returns or the existence of the bilateral relation between them.

Despite the increasing trading of ETFs in financial market, helping to enhance the liquidity of security in recent decades, the research which empirically documented the link between ETFs performance and their impacts of spillover and leverage effect is still scarce, especially for precious metal ETFs. This study contributes new look on financial time series literature related precious and base metal ETFs and may be implemented for other financial instruments, especially for researchers and policymakers. Investors based on empirical results might have appropriate strategies to avoid risk and make profits through optimal portfolio.

\section{Data and Methodology}

This study chose four precious metal ETFs and four base metal ETFs to test for 
spillover effect based on their highest market capitalization. The less (or nearzero) transaction volume can be avoided for excluding smaller market capitalization. This study investigates spillover effects from January 21, 2005 to June 30, 2013. Daily data for precious metal and base metal ETFs are the daily closing prices, which are collected from the Yahoo Finance website. The precious metal (base metal) prices are obtained from the cnyes website ${ }^{1}$. However, the data are based on the different inception dates of precious metal and base metal ETFs. The highest market capitalization for precious metal ETFs is SPDR Gold Shares (ticker: GLD), with the market capitalization is US $\$ 45816.1$ million. The highest market capitalization for base metal ETFs is iPath DJ-UBS Copper TR Sub-Index ETN (ticker: JJC) and the market capitalization is US $\$ 106,073$ million.

The spillover and leverage effects of precious metal ETFs were captured by the $\operatorname{GARCH}(p, q)$-M-ARMA $(g, s)$ as well as the $\operatorname{EGARCH}(p, q)$-M-ARMA $(g, s)$ models to examine if the time series performed heteroskedasticity. The return on a specific ETF is assumed as the equation below and ordinarily takes the logarithm of relevant price as:

$$
\begin{aligned}
& R_{i, t}^{m}=\ln \left(\frac{I_{i, t}}{I_{i, t-1}}\right) * 100, \\
& R_{i, t}^{e}=\ln \left(\frac{P_{i, t}}{P_{i, t-1}}\right) * 100,
\end{aligned}
$$

where $R_{i, t}^{m}$ and $R_{i, t}^{e}$ stand for the precious metal (base metal) ETF and precious metal (base metal) index returns at time $t$, respectively;

$I_{i, t}$ denotes ith precious metal (base metal) price index at time $t$, and $P_{i, t}$ identifies $i$ th the precious metal (base metal) ETF at the time $t$.

The EGARCH was developed by Nelson [17], and was applied by Chen [3] and Chen and Diaz [18] based on the conditional heterokedasticity and asymmetric volatility. This article captures the spillover and leverage effects of both precious metal ETFs and precious metal indices through a mixture of the GARCH $(p, q)$-M-ARMA $(g, s)$ and EGARCH $(p, q)$-M-ARMA $(g, s)$ models. Chou [19] and Lanne and Saikkonen [20] mentioned the GARCH-in-Mean model derived from an alternative distribution, namely, $z$ distribution, which can be determined as a variance-mean mixture of normal distributions. The GARCH-M model was applied to examine the relationship between risk and return in daily data of the precious metal (base metal) ETF and precious metal (base metal) price index.

The model for precious metal (base metal) ETFs are determined as follows:

$$
\begin{aligned}
& R_{i, t}^{e}=\alpha_{0}+\sum_{i=1}^{g} \alpha_{i} R_{i, t-i}^{e}+\varepsilon_{i, t}^{e}+\sum_{i=1}^{s} \theta_{i} \varepsilon_{i, t-i}^{e}+z h_{i, t}^{e}, \\
& h_{i, t}^{e^{2}}=a_{0}+\sum_{i=1}^{q} a_{i} \varepsilon_{i, t-i}^{e^{2}}+\sum_{i=1}^{p} \psi_{i} h_{i, t-i}^{e^{2}}, \text { for GARCH }
\end{aligned}
$$

1http://www.cnyes.com. 


$$
\begin{gathered}
\log \left(h_{i, t}^{e^{2}}\right)=a_{0}+\sum_{i=1}^{q}\left(a_{i}\left|\frac{\varepsilon_{i, t-i}^{e}}{h_{i, t-i}^{e}}\right|+\delta_{i} \frac{\varepsilon_{i, t-i}^{e}}{h_{i, t-i}^{e}}\right)+\sum_{i=1}^{p} \psi_{i} \log \left(h_{i, t-i}^{e^{2}}\right), \text { for EGARCH } \\
\varepsilon_{i, t}^{e} \mid \psi_{t-1} \sim N\left(0, h_{i, t}^{e}\right),
\end{gathered}
$$

where $R_{i, t}^{e}$ denotes the $i$ th precious metal (base metal) ETF return at time $t, z$ distribution is modeled after moderate skewness and kurtosis to meet the demand of skewness test, $\sum_{i=1}^{g} \alpha_{i} R_{i, t-i}^{e}$ stands for the higher order of the autogressive $\operatorname{AR}(g)$ for ETF returns, $\varepsilon_{i, t}^{e}$ identifies the precious metal (base metal) ETF return residuals at time $t, \varepsilon_{i, t}^{e}+\sum_{i=1}^{s} \theta_{i} \varepsilon_{i, t-i}^{e}$ is the higher order moving average mean process MA $(s)$ for $R_{i, t}^{e}, \sum_{i=1}^{p} \psi_{i} h_{i, t-i}^{e^{2}}$ stands for the $p$ order conditional heterokedasticity of the GARCH term for ETF returns at the time $t, \sum_{i=1}^{q} a_{i} \varepsilon_{i, t-i}^{e^{2}}$ is the $q$ order of the ARCH term for ETF returns at the time $t, \psi_{t-1}$ reveals all the information set at time $t-1, \delta_{i}$ indicates the leverage term, and $\theta_{i}$ stands for the unknown parameter.

The residual series has to show evidence of heterokadasticity. Thus, the equation below supports that assumption as:

$$
\varepsilon_{t}^{2}=\alpha_{0}+k_{1} \varepsilon_{t-1}^{2}+k_{2} \varepsilon_{t-2}^{2}+\cdots+k_{p} \varepsilon_{t-p}^{2}+z_{t}
$$

The residual series will not reach zero, hence the null hypothesis of the correlation among $p=n$ periods is rejected. The residual series exists in the heterokadasticity.

The spillover and leverage effects for ETF returns are estimated through the following equation:

$$
\begin{gathered}
R_{i, t}^{m}=\beta_{0}+\sum_{i=1}^{g} \beta_{i} R_{i, t-i}^{m}+\varepsilon_{i, t}^{m}+\sum_{i=1}^{s} \gamma_{i} \varepsilon_{i, t-i}^{m}+k h_{i, t}^{m}, \\
h_{i, t}^{m^{2}}=b_{0}+\sum_{i=1}^{q} b_{i} \varepsilon_{i, t-i}^{m^{2}}+\sum_{i=1}^{p} \zeta_{i} h_{i, t-i}^{m^{2}}, \text { for GARCH } \\
\log \left(h_{i, t}^{m^{2}}\right)=b_{0}+\sum_{i=1}^{q}\left(b_{i}\left|\frac{\varepsilon_{i, t-i}^{m}}{h_{i, t-i}^{m}}\right|+\delta_{i} \frac{\varepsilon_{i, t-i}^{m}}{h_{i, t-i}^{m}}\right)+\sum_{i=1}^{p} \zeta_{i} \cdot \log \left(h_{i, t-i}^{m^{2}}\right), \text { for EGARCH, } \\
\varepsilon_{i, t}^{m} \mid \psi_{t-1} \sim N\left(0, h_{i, t}^{m}\right)
\end{gathered}
$$

where $R_{i, t}^{m}$ denotes the $i$ th precious metal index return at time $t, \varepsilon_{i, t}^{m}$ identifies the residual of precious metal index residuals at time $t, h_{i, t}^{m}$ stands for the conditional variance of index at the time $t, \delta_{i}$ indicates the leverage term, and $\gamma_{i}$ stands for the unknown parameter.

$h_{i, t}^{e^{2}}$ and $h_{i, t}^{m^{2}}$ are the conditional variances of ETFs and precious metal index returns.

$w$ and $d$ are the coefficients that present the spillover effects between precious metal (base metal) ETF returns and precious metal (base metal) index returns. 
In this test, null hypothesis illustrates no effect of return ( $w=0 ; d=0)$. The spillover effects appear when $w$ and $d$ coefficients are significant from zero and vice versa.

$z$ and $k$ coefficients denote the relationship between risk and return for the standard deviation, and should be positive such as in the previous studies of Chou [19] and Lanne and Saikkonen [20] in the GARCH-M model.

In this part, the test of leverage effects is employed to capture the asymmetric volatility parameter $\left(\delta_{i}\right)$ that is given in the EGARCH model. The significance of a negative value for $\delta$ represents the appearance of the leverage effect in precious metal index returns within the sample period.

To determine the spillover effect of returns and volatilities for precious metal index as well as precious ETFs, the multiple $\operatorname{GARCH}(p, g)$-M-ARMA $(g, s)$ and EGARCH $(p, g)$-M-ARMA $(g, s)$ models were utilized. The estimations are exhibited in the following:

\section{1) The spillover effect on returns}

This part details the reason why spillover effects can allow accuracy on the interdependence between precious metal (base metal) ETF returns and precious metal (base metal) index returns, and how they can affect each other by market shocks (news). It is given as:

$$
\begin{gathered}
R_{i, t}^{e}=\alpha_{0}+\sum_{i=1}^{g} \alpha_{i} R_{i, t-i}^{e}+w R_{i, t-1}^{m}+\varepsilon_{i, t}^{e}+\sum_{i=1}^{s} \theta_{i} \varepsilon_{i, t-i}^{e}+z h_{i, t}^{e}, \\
h_{i, t}^{e^{2}}=a_{0}+\sum_{i=1}^{q} a_{i} \varepsilon_{i, t-i}^{e^{2}}+\sum_{i=1}^{p} \psi_{i} h_{i, t-i}^{e^{2}}, \text { for GARCH } \\
\log \left(h_{i, t}^{e^{2}}\right)=a_{0}+\sum_{i=1}^{q}\left(a_{i}\left|\frac{\varepsilon_{i, t-i}^{e}}{h_{i, t-i}^{e}}\right|+\delta_{i} \frac{\varepsilon_{i, t-i}^{e}}{h_{i, t-i}^{e}}\right)+\sum_{i=1}^{p} \psi_{i} \log \left(h_{i, t-i}^{e^{2}}\right), \text { for EGARCH }(12) \\
R_{i, t}^{m}=\beta_{0}+\sum_{i=1}^{g} \beta_{i} R_{i, t-i}^{m}+d R_{i, t-1}^{e}+\varepsilon_{i, t}^{m}+\sum_{i=1}^{s} \gamma_{i} \varepsilon_{i, t-i}^{m}+k h_{i, t}^{m}, \\
\log \left(h_{i, t}^{m^{2}}\right)=b_{0}+\sum_{i=1}^{q}\left(h_{i, t}^{m^{2}}=b_{0}+\sum_{i=1}^{q} b_{i} \varepsilon_{i, t-i}^{m^{2}}+\sum_{i=1}^{p} \zeta_{i} h_{i, t-i}^{m^{2}},\right. \text { for GARCH } \\
\left.h_{i, t-i}^{m} \mid+h_{i, t}^{e}\right) \\
\varepsilon_{i, t}^{m} \mid \psi_{t-1} \sim N\left(0, h_{i, t}^{m}\right)
\end{gathered}
$$

where $w$ and $d$ identify the spillover effects from precious metal (base metal) index returns and precious metal (base metal) ETF returns.

To test spillover effects, the null hypothesis of no spillover effects of returns $(w=0 ; d=0)$ exist. When the $w$ coefficient is found significant and different from zero, the lagged precious metal (base metal) index returns is understood to affect precious metal (base metal) ETF returns and vice versa, if the $d$ coefficient is tested. On the other hand, the positive relationship between risks and returns 
is observed whether it exists in precious metal (base metal) ETF returns through GARCH-M application.

\section{2) The spillover effect of volatilities}

This part also broadens the possible spillover effects by considering the influence of cross-market dynamics on precious metal index volatilities and precious metal (base metal) ETF volatilities. The equations are described as:

$$
\begin{gathered}
R_{i, t}^{e}=\alpha_{0}+\sum_{i=1}^{g} \alpha_{i} R_{i, t-i}^{e}+\varepsilon_{i, t}^{e}+\sum_{i=1}^{s} \theta_{i} \varepsilon_{i, t-i}^{e}+z h_{i, t}^{e} \\
h_{i, t}^{e^{2}}=a_{0}+\sum_{i=1}^{q} a_{i} \varepsilon_{i, t-i}^{e^{2}}+\sum_{i=1}^{p} \psi_{i} h_{i, t-i}^{e^{2}}+v \varepsilon_{i, t-1}^{m^{2}}, \text { For GARCH } \\
\log \left(h_{i, t}^{e^{2}}\right)=a_{0}+\sum_{i=1}^{q}\left(a_{i}\left|\frac{\varepsilon_{i, t-i}^{e} \mid}{h_{i, t-i}^{e}}\right|+\delta_{i} \frac{\varepsilon_{i, t-i}^{e}}{h_{i, t-i}^{e}}\right)+\sum_{i=1}^{p} \psi_{i} \log \left(h_{i, t-i}^{e^{2}}\right)+v \varepsilon_{i, t-1}^{m^{2}}, \text { for EGARCH } \\
R_{i, t}^{m}=\beta_{0}+\sum_{i=1}^{g} \beta_{i} R_{i, t-i}^{m}+\varepsilon_{i, t}^{m}+\sum_{i=1}^{s} \gamma_{i} \varepsilon_{i, t-i}^{m}+k h_{i, t}^{m}, \\
h_{i, t}^{m^{2}}=b_{0}+\sum_{i=1}^{q} b_{i} \varepsilon_{i, t-i}^{m^{2}}+\sum_{i=1}^{p} \zeta_{i} h_{i, t-i}^{m^{2}}+l \varepsilon_{i, t-1}^{e^{2}}, \text { for GARCH } \\
\log \left(h_{i, t}^{m^{2}}\right)=b_{0}+\sum_{i=1}^{q}\left(b_{i}\left|\frac{\varepsilon_{i, t-i}^{m}}{h_{i, t-i}^{m}}\right|+\delta_{i} \frac{\varepsilon_{i, t-i}^{m}}{h_{i, t-i}^{m}}\right)+\sum_{i=1}^{p} \zeta_{i} \cdot \log \left(h_{i, t-i}^{m^{2}}\right)+l \varepsilon_{i, t-1}^{e^{2}}, \text { for EGARCH }
\end{gathered}
$$

where $V$ and $l$ identify the spillover effects from precious metal (base metal) index volatilities and precious metal (base metal) ETF volatilities.

The test of spillover effects is under the null hypothesis that there are no spillover effects of volatilities $(v=0 ; l=0)$ against the alternative hypotheses that there are spillover effects of volatilities. When the p-value of $v$ (or $I$ ) coefficient is lower than alpha value, the lagged precious metal index volatilities are understood to affect precious metal ETF volatilities and vice versa. GARCH-M specification helps to indicate if the positive relationship appears between risks and returns of precious metal (base metal) ETF volatilities and precious metal (base metal) price index volatilities. The findings of utilizing these models were found to be significant in the previous studies of Chou [19], Lanne and Saikkonen [20], Chen [3], and Chen and Diaz [18].

\section{Empirical Results}

Table 1 presents the average returns of precious metal and base metal ETFs since their inception date. The gold price had the highest return of $0.454 \%$, whereas nickel price received the lowest return at -11.92 . The samples were negatively skewed and the kurtosis coefficients had leptokurtic distributions. Moreover, the Jarque-Bera was used to test for residual normality, and showed that all 
Table 1. Summary statistics.

\begin{tabular}{|c|c|c|c|c|c|c|c|c|}
\hline & ETFs and index & Period & Obs. & Means & Std. Dev. & Skew. & Kurt. & J-Bera \\
\hline \multicolumn{9}{|c|}{ Precious metal ETFs } \\
\hline 1 & $\begin{array}{l}\text { SPDR gold shares (GLD)/ } \\
\text { Gold price }\end{array}$ & $\begin{array}{c}2004 / 11 / 18- \\
2013 / 5 / 31\end{array}$ & $\begin{array}{l}2098 \\
2098\end{array}$ & $\begin{array}{l}0.043 \\
0.454\end{array}$ & $\begin{array}{c}1.393 \\
14.361\end{array}$ & $\begin{array}{l}-0.763 \\
-0.881\end{array}$ & $\begin{array}{l}11.183 \\
12.579\end{array}$ & $\begin{array}{l}6057.11^{* * *} \\
8292.92^{* * *}\end{array}$ \\
\hline 2 & $\begin{array}{l}\text { Ishare silver trust (SLV)/ } \\
\text { Silver price }\end{array}$ & $\begin{array}{c}2006 / 04 / 21- \\
2013 / 5 / 31\end{array}$ & $\begin{array}{l}1759 \\
1759\end{array}$ & $\begin{array}{l}0.005 \\
0.006\end{array}$ & $\begin{array}{l}0.558 \\
0.647\end{array}$ & $\begin{array}{l}-2.141 \\
-1.099\end{array}$ & $\begin{array}{l}24.222 \\
22.021\end{array}$ & $\begin{array}{l}34352.25^{\star * *} \\
26870.9^{* * *}\end{array}$ \\
\hline 3 & $\begin{array}{l}\text { Physical palladium shares (PALL)/ } \\
\text { Palladium price index }\end{array}$ & $\begin{array}{c}2010 / 01 / 08- \\
2013 / 5 / 31\end{array}$ & $\begin{array}{l}816 \\
816\end{array}$ & $\begin{array}{l}0.031 \\
0.302\end{array}$ & $\begin{array}{c}1.309 \\
13.448\end{array}$ & $\begin{array}{l}-0.390 \\
-0.451\end{array}$ & $\begin{array}{l}4.090 \\
4.256\end{array}$ & $\begin{array}{l}61.08^{\star * *} \\
81.366^{* * *}\end{array}$ \\
\hline 4 & $\begin{array}{l}\text { E-TRACTS UBS long platinum ETN (PTM)/ } \\
\text { Platinum price }\end{array}$ & $\begin{array}{c}\text { 2008/05/08 - } \\
2013 / 5 / 31 \\
\text { Base metal }\end{array}$ & $\begin{array}{r}1243 \\
1243 \\
\text { Fs }\end{array}$ & $\begin{array}{l}-0.007 \\
-0.439\end{array}$ & $\begin{array}{c}0.393 \\
23.327\end{array}$ & $\begin{array}{l}-0.418 \\
-0.673\end{array}$ & $\begin{array}{c}12.222 \\
5.186\end{array}$ & $\begin{array}{l}4440.53^{* * *} \\
340.59^{* * *}\end{array}$ \\
\hline 1 & $\begin{array}{l}\text { DJ-UBS copper total return sub-index ETN (JJC)/ } \\
\text { Copper price }\end{array}$ & $\begin{array}{c}2007 / 10 / 23- \\
2013 / 5 / 31\end{array}$ & $\begin{array}{l}1375 \\
1375\end{array}$ & $\begin{array}{l}-0.007 \\
-0.350\end{array}$ & $\begin{array}{c}0.878 \\
138.549\end{array}$ & $\begin{array}{l}-0.235 \\
-0.120\end{array}$ & $\begin{array}{l}4.023 \\
3.952\end{array}$ & $\begin{array}{l}72.78^{\star * *} \\
55.23^{\star * *}\end{array}$ \\
\hline 2 & $\begin{array}{l}\text { DJ-UBS nickel total return sub-index ETN (JJN)/ } \\
\text { Nickel price }\end{array}$ & $\begin{array}{c}2007 / 10 / 23- \\
2013 / 5 / 31\end{array}$ & $\begin{array}{l}1379 \\
1379\end{array}$ & $\begin{array}{l}-0.021 \\
-11.92\end{array}$ & $\begin{array}{c}0.771 \\
507.022\end{array}$ & $\begin{array}{l}-0.301 \\
-0.100\end{array}$ & $\begin{array}{l}5.342 \\
5.462\end{array}$ & $\begin{array}{l}336.14^{\star * *} \\
350.14^{\star * \star}\end{array}$ \\
\hline 3 & $\begin{array}{c}\text { DJ-UBS tin total return sub-index ETN }(\mathrm{JJT}) / \\
\text { Tin price }\end{array}$ & $\begin{array}{c}2008 / 06 / 24- \\
2013 / 5 / 31\end{array}$ & $\begin{array}{l}1209 \\
1209\end{array}$ & $\begin{array}{l}-0.001 \\
-1.300\end{array}$ & $\begin{array}{c}1.005 \\
434.002\end{array}$ & $\begin{array}{l}-0.461 \\
-0.283\end{array}$ & $\begin{array}{l}6.613 \\
5.045\end{array}$ & $\begin{array}{l}700.36^{* * *} \\
226.46^{* * *}\end{array}$ \\
\hline 4 & $\begin{array}{l}\text { DJ-UBS lead total return sub-index ETN (LD)/ } \\
\text { Lead index }\end{array}$ & $\begin{array}{c}2008 / 06 / 24- \\
2013 / 5 / 31\end{array}$ & $\begin{array}{l}1209 \\
1209\end{array}$ & $\begin{array}{l}0.006 \\
0.196\end{array}$ & $\begin{array}{c}1.391 \\
51.858\end{array}$ & $\begin{array}{l}-0.283 \\
-0.235\end{array}$ & $\begin{array}{l}5.727 \\
4.819\end{array}$ & $\begin{array}{l}390.86^{* * *} \\
177.67^{* * *}\end{array}$ \\
\hline
\end{tabular}

Note: ${ }^{*}{ }^{* *}$ and ${ }^{* *}$ are significance at 10,5 and $1 \%$ levels, respectively.

ETF returns were under a non-normal distribution assumption.

The ADF unit root test is utilized to test the null hypothesis of stationary of a time series in Table 2. The Akaike Information Criterion was used to choose the optimal ARMA, GARCH, and EGARCH models based on the minimum value. The null hypothesis for serial correlation of all precious metal (base metal) ETF and precious metal (base metal) price returns cannot be rejected using the Breush-Godfrey LM test. The ARCH-LM test was considered to test for the $\mathrm{ARCH}$ effects that the null hypothesis of no ARCH effect of all the time series was rejected. The ARCH-LM test was carried out to examine the hypothesis with no autoregressive conditional heterokedasticity for both GARCH-M-ARMA and EGARCH-M-ARMA.

EGARCH-M-ARMA models were applied to capture the leverage effects through analyzing the significance of autocorrelation. The precious metal (base metal) ETF and precious metal (base metal) price returns were verified through conditional heterokedasticity. According to previous papers on asymmetry returns by Kanas [11], Bhar and Nikolova [6], Chen and Huang [16], and Chen [3], the results of GARCH-M-ARMA and EGARCH-M-ARMA estimation in the presence of leverage effects and spillover effects are detailed in Table 3. The coefficient of leverage effects $(\delta$ ) indicated a significant negative asymmetric 
Table 2. Summary statistics of unit root, LM, ARMA-LM tests.

\begin{tabular}{|c|c|c|c|c|c|c|c|c|c|c|c|c|}
\hline & $\begin{array}{l}\text { ETFS/ } \\
\text { Indices }\end{array}$ & $\mathrm{ADF}$ & ARMA & AIC & LM & ARCH-LM & GARCH & AIC & ARCH-LM & EGARCH & AIC & ARCH-LM \\
\hline \multicolumn{13}{|c|}{ Precious metal ETFs } \\
\hline \multirow[t]{2}{*}{1} & GLD/ & $-46.228^{* * *}$ & (3.3) & 3.503 & 0.116 & $101.379^{* * *}$ & $(3.2)$ & 3.014 & 3.755 & $(0.3)$ & 3.316 & 0.127 \\
\hline & Gold & $-33.757^{\star * *}$ & $(2.2)$ & 8.157 & 0.936 & $52.747^{\star * *}$ & $(2.1)$ & 7.674 & 0.255 & (3.3) & 7.640 & 0.575 \\
\hline \multirow[t]{2}{*}{2} & SLV/ & $-18.578^{\star * *}$ & $(2.2)$ & 1.666 & 0.215 & $309.016^{* * *}$ & (3.3) & 1.088 & 3.223 & $(0.2)$ & 1.380 & 0.043 \\
\hline & Silver & $-48.367^{\star \star *}$ & (2.3) & 1.940 & 2.908 & $454.821^{* * *}$ & (3.3) & 1.313 & 0.329 & (3.3) & 1.288 & 0.240 \\
\hline \multirow[t]{2}{*}{3} & PALL/ & $-26.369^{* * *}$ & $(2.2)$ & 3.365 & 1.136 & $17.424^{\star \star \star}$ & (3.1) & 3.322 & 1.903 & $(3.2)$ & 3.313 & 0.302 \\
\hline & Palladium & $-29.466^{* * *}$ & (3.3) & 8.028 & 0.205 & 3.747659 & $(3.2)$ & 7.977 & 1.727 & $(2.2)$ & 7.977 & 1.342 \\
\hline \multirow[t]{2}{*}{4} & PTM/ & $-20.430^{* * *}$ & $(3.2)$ & 0.951 & 0.162 & $160.041^{* * *}$ & (3.3) & 0.594 & 1.424 & $(3.1)$ & 0.609 & 2.516 \\
\hline & Platinum & $-32.049^{* * *}$ & (3.3) & 9.115 & 1.093 & $23.969^{* * *}$ & $(3.2)$ & 9.022 & 0.268 & (3.3) & 9.009 & 1.119 \\
\hline \multicolumn{13}{|c|}{ Base metal ETFs } \\
\hline \multirow[t]{2}{*}{1} & JJC/ & $-25.954^{* * *}$ & (3.3) & 2.560 & 1.313 & $25.616^{* * *}$ & $(3.2)$ & 2.477 & 0.367 & $(3.1)$ & 2.472 & 1.521 \\
\hline & Copper & $-39.043^{\star * *}$ & $(3.2)$ & 12.700 & 0.513 & $51.822^{\star * *}$ & (2.3) & 12.611 & 0.206 & $(1.2)$ & 12.598 & 0.141 \\
\hline \multirow[t]{2}{*}{2} & JJN/ & $-38.002^{* * *}$ & $(2.2)$ & 2.325 & 0.238 & $48.242^{\star * *}$ & $(1.1)$ & 2.165 & 0.061 & (3.3) & 2.165 & 2.913 \\
\hline & Nickel & $-37.707^{\star * *}$ & (3.3) & 15.293 & 0.078 & $45.740^{* * *}$ & (1.3) & 15.117 & 0.304 & $(1.3)$ & 15.105 & 0.338 \\
\hline \multirow[t]{2}{*}{3} & JJT/ & $-32.939^{* * *}$ & $(2.3)$ & 2.847 & 1.512 & $28.158^{\star * *}$ & $(3.1)$ & 2.769 & 1.021 & $(3.1)$ & 2.753 & 2.642 \\
\hline & Tin & $-33.451^{* * *}$ & $(2.2)$ & 14.977 & 1.699 & $25.661^{\star * *}$ & $(3.1)$ & 14.904 & 0.400 & $(3.1)$ & 14.897 & 0.417 \\
\hline \multirow[t]{2}{*}{4} & $\mathrm{LD} /$ & $-34.449^{* * *}$ & $(3.2)$ & 3.485 & 1.045 & $7.595^{\star *}$ & (3.3) & 3.415 & 3.048 & $(0.1)$ & 3.478 & 0.00002 \\
\hline & Lead & $-32.842^{* * *}$ & (2.3) & 10.737 & 0.497 & $22.106^{* * *}$ & (3.3) & 10.616 & 0.390 & (3.2) & 10.602 & 0.051 \\
\hline
\end{tabular}

Note: ${ }^{*}{ }^{* *}$ and ${ }^{* *}$ are significance at 10,5 and $1 \%$ levels, respectively; $p$-values are in parentheses.

volatility effect in most precious metal (base metal) ETFs and precious metal (base metal) prices. Nonetheless, a positive asymmetric volatility effect was shown for the lagged of silver price to the current return of the silver ETF. By employing both GARCH-M-ARMA and EGARCH-M-ARMA approaches, this paper takes into account the spillover effect of precious metal (base metal) ETF and precious metal (base metal) price on returns and volatilities and vice versa.

\section{1) Spillover effect of return}

The GARCH-M-ARMA model the coefficient of lagged precious metal (base metal) price returns (w) and lagged (base metal) ETF returns were observed to have an effect on the current precious metal (base metal) price returns and precious metal (base metal) ETF returns. Table 3 shows the positive effect of lagged precious metal (base metal) price returns to ETF returns that were significant at the $1 \%$ level for GLD, JJN, JJT, and LD, and at the $10 \%$ level for PTM. This finding is accordance with the previous studies of Chen and Huang [16], Chen [3] and Chen and Diaz [18] who presented evidence of positive returns transmission on ETFs.

With precious metal ETFs, GLD was found to have a significant positive bilateral relationship with precious metal prices at the $10 \%$ level. If there is an increase (decrease) in the price of precious metal return in previous to the trading 
Table 3. Spillover effects of returns and volatilities for precious metal (base metal) ETF and their index returns.

\begin{tabular}{|c|c|c|c|c|c|c|c|c|c|c|c|c|}
\hline \multirow{4}{*}{$\begin{array}{l}\text { ETFs and } \\
\text { indices }\end{array}$} & \multicolumn{4}{|c|}{ Spillover effects of returns } & \multicolumn{4}{|c|}{ Spillover effects of volatilities } & \multirow{2}{*}{\multicolumn{2}{|c|}{$\begin{array}{c}\text { Risk effects } \\
\text { EGARCH-ARMA }\end{array}$}} & \multirow{2}{*}{\multicolumn{2}{|c|}{$\begin{array}{r}\text { Leverage effects } \\
\text { EGARCH-ARMA }\end{array}$}} \\
\hline & \multicolumn{2}{|c|}{ GARCH-ARMA } & \multicolumn{2}{|c|}{ EGARCH-ARMA } & \multicolumn{2}{|c|}{ GARCH-ARMA } & \multicolumn{2}{|c|}{ EGARCH-ARMA } & & & & \\
\hline & Price & ETFs & Price & ETFs & Price & ETFs & Price & ETFs & Price & ETFs & Price & ETFs \\
\hline & $d$ & $w$ & $d$ & $w$ & 1 & $\boldsymbol{v}$ & 1 & $\boldsymbol{v}$ & $k$ & $z$ & $\delta$ & $\delta$ \\
\hline \multicolumn{13}{|c|}{ Precious metal ETFs } \\
\hline $\begin{array}{l}\text { GLD/ } \\
\text { gold }\end{array}$ & $\begin{array}{c}9.951 \\
(0.000) \\
* * *\end{array}$ & $\begin{array}{c}0.008 \\
(0.008) \\
\star * \star\end{array}$ & $\begin{array}{c}9.970 \\
(0.000) \\
\star * \star\end{array}$ & $\begin{array}{c}0.009 \\
(0.003) \\
* * *\end{array}$ & $\begin{array}{c}15.755 \\
(0.000) \\
\star * *\end{array}$ & $\begin{array}{r}0.00001 \\
(0.177)\end{array}$ & $\begin{array}{c}0.027 \\
(0.000) \\
* * *\end{array}$ & $\begin{array}{c}0.0002 \\
(0.000) \\
\star * \star\end{array}$ & $\begin{array}{c}0.005 \\
(0.173)\end{array}$ & $\begin{array}{c}0.037 \\
(0.327)\end{array}$ & $\begin{array}{c}-0.038 \\
(0.000) \\
\star \star \star\end{array}$ & $\begin{array}{c}-0.115 \\
(0.000) \\
\star * \star\end{array}$ \\
\hline $\begin{array}{l}\text { SLV/ } \\
\text { silver }\end{array}$ & $\begin{array}{c}1.002 \\
(0.000) \\
* * *\end{array}$ & $\begin{array}{l}-0.017 \\
(0.464)\end{array}$ & $\begin{array}{c}1.003 \\
(0.000) \\
* * *\end{array}$ & $\begin{array}{c}-0.108 \\
(0.000) \\
\star * *\end{array}$ & $\begin{array}{c}0.677 \\
(0.000) \\
\star * *\end{array}$ & $\begin{array}{c}0.002 \\
(0.009) \\
\star * \star\end{array}$ & $\begin{array}{c}0.113 \\
(0.000) \\
* * *\end{array}$ & $\begin{array}{c}0.147 \\
(0.000) \\
\star * \star\end{array}$ & $\begin{array}{c}0.004 \\
(0.244)\end{array}$ & $\begin{array}{c}-0.682 \\
(0.000) \\
* * *\end{array}$ & $\begin{array}{r}-0.0003 \\
(0.991)\end{array}$ & $\begin{array}{c}0.004 \\
(0.000) \\
\star * *\end{array}$ \\
\hline $\begin{array}{c}\text { PALL/ } \\
\text { palladium }\end{array}$ & $\begin{array}{c}8.852 \\
(0.000) \\
* * *\end{array}$ & $\begin{array}{l}-0.006 \\
(0.145)\end{array}$ & $\begin{array}{c}8.794 \\
(0.000) \\
* * *\end{array}$ & $\begin{array}{l}-0.005 \\
(0.126)\end{array}$ & $\begin{array}{c}39.468 \\
(0.000) \\
* * *\end{array}$ & $\begin{array}{c}0.004 \\
(0.000) \\
\star * \star\end{array}$ & $\begin{array}{l}-0.042 \\
(0.353)\end{array}$ & $\begin{array}{c}-0.175 \\
(0.000) \\
\star * \star\end{array}$ & $\begin{array}{c}0.003 \\
(0.979)\end{array}$ & $\begin{array}{l}-0.313 \\
(0.231)\end{array}$ & $\begin{array}{c}-0.088 \\
(0.003) \\
\star * *\end{array}$ & $\begin{array}{c}-0.262 \\
(0.000) \\
\star * \star\end{array}$ \\
\hline $\begin{array}{l}\text { PTM/ } \\
\text { platinum }\end{array}$ & $\begin{array}{c}30.631 \\
(0.000) \\
* * *\end{array}$ & $\begin{array}{l}0.0004 \\
(0.668)\end{array}$ & $\begin{array}{c}30.766 \\
(0.000) \\
\star * *\end{array}$ & $\begin{array}{c}0.001 \\
(0.322)\end{array}$ & $\begin{array}{c}251.969 \\
(0.000) \\
\star * *\end{array}$ & $\begin{array}{l}0.0000 \\
(0.511)\end{array}$ & $\begin{array}{c}0.146 \\
(0.000) \\
\star * \star\end{array}$ & $\begin{array}{r}0.00001 \\
(0.633)\end{array}$ & $\begin{array}{c}0.056 \\
(0.504)\end{array}$ & $\begin{array}{c}-0.359 \\
(0.005) \\
* *\end{array}$ & $\begin{array}{c}-0.038 \\
(0.008) \\
\star * *\end{array}$ & $\begin{array}{c}0.007 \\
(0.711)\end{array}$ \\
\hline \multicolumn{13}{|c|}{ Base metal ETFs } \\
\hline $\begin{array}{l}\text { JJC/ } \\
\text { copper }\end{array}$ & $\begin{array}{c}125.455 \\
(0.000) \\
\star * \star\end{array}$ & $\begin{array}{c}0.000 \\
(0.903)\end{array}$ & $\begin{array}{c}125.823 \\
(0.000) \\
* * *\end{array}$ & $\begin{array}{c}0.000 \\
(0.755)\end{array}$ & $\begin{array}{c}1222.941 \\
(0.012) \\
\star \star\end{array}$ & $\begin{array}{c}0.000 \\
(0.094) \\
*\end{array}$ & $\begin{array}{c}0.048 \\
(0.010) \\
\star * *\end{array}$ & $\begin{array}{c}0.000 \\
(0.606)\end{array}$ & $\begin{array}{l}-0.011 \\
(0.932)\end{array}$ & $\begin{array}{c}0.047 \\
(0.694)\end{array}$ & $\begin{array}{c}0.033 \\
(0.834)\end{array}$ & $\begin{array}{c}0.042 \\
(0.747)\end{array}$ \\
\hline $\begin{array}{l}\text { JJN/ } \\
\text { nickel }\end{array}$ & $\begin{array}{c}143.739 \\
(0.000) \\
\star * \star\end{array}$ & $\begin{array}{c}0.001 \\
(0.000) \\
\star * \star\end{array}$ & $\begin{array}{l}8.685 \\
(0.612)\end{array}$ & $\begin{array}{c}0.001 \\
(0.000) \\
* * *\end{array}$ & $\begin{array}{c}9278.264 \\
(0.001) \\
\star \star \star\end{array}$ & $\begin{array}{c}0.000 \\
(0.000) \\
\star \star \star\end{array}$ & $\begin{array}{c}0.013 \\
(0.003) \\
* * *\end{array}$ & $\begin{array}{c}0.000 \\
(0.085) \\
*\end{array}$ & $\begin{array}{l}-0.092 \\
(0.196)\end{array}$ & $\begin{array}{c}-0.188 \\
(0.005) \\
* *\end{array}$ & $\begin{array}{l}-0.120 \\
(0.115)\end{array}$ & $\begin{array}{c}-0.194 \\
(0.048) \\
\star \star\end{array}$ \\
\hline $\begin{array}{l}\mathrm{JJT} / \\
\text { tin }\end{array}$ & $\begin{array}{c}92.049 \\
(0.000) \\
\star * *\end{array}$ & $\begin{array}{c}0.001 \\
(0.000) \\
\star \star \star\end{array}$ & $\begin{array}{c}96.735 \\
(0.000) \\
\star * \star\end{array}$ & $\begin{array}{c}0.001 \\
(0.000) \\
* * *\end{array}$ & $\begin{array}{c}21437.49 \\
(0.000) \\
\star \star \star\end{array}$ & $\begin{array}{c}0.001 \\
(0.000) \\
\star * \star\end{array}$ & $\begin{array}{c}0.045 \\
(0.000) \\
* * *\end{array}$ & $\begin{array}{c}0.000 \\
(0.000) \\
\star * *\end{array}$ & $\begin{array}{c}-0.354 \\
(0.026) \\
\star \star\end{array}$ & $\begin{array}{l}-0.140 \\
(0.154)\end{array}$ & $\begin{array}{l}-0.261 \\
(0.068)^{*}\end{array}$ & $\begin{array}{l}-0.208 \\
(0.155)\end{array}$ \\
\hline $\begin{array}{l}\text { LD/ } \\
\text { lead }\end{array}$ & $\begin{array}{c}3.099 \\
(0.018) \\
\star *\end{array}$ & $\begin{array}{c}0.015 \\
(0.000) \\
\star \star \star\end{array}$ & $\begin{array}{c}2.301 \\
(0.081) \\
*\end{array}$ & $\begin{array}{c}0.014 \\
(0.000) \\
\star * \star\end{array}$ & $\begin{array}{l}15.537 \\
(0.176)\end{array}$ & $\begin{array}{c}0.000 \\
(0.002) \\
\star \star \star\end{array}$ & $\begin{array}{c}0.000 \\
(0.943)\end{array}$ & $\begin{array}{c}0.000 \\
(0.000) \\
\star * \star\end{array}$ & $\begin{array}{l}-0.118 \\
(0.273)\end{array}$ & $\begin{array}{c}-0.390 \\
(0.099) \\
*\end{array}$ & $\begin{array}{l}-0.013 \\
(0.907)\end{array}$ & $\begin{array}{c}-0.238 \\
(0.107) \\
\star\end{array}$ \\
\hline
\end{tabular}

Note: ${ }^{*}{ }^{* *}$ and ${ }^{* *}$ are significance at 10,5 and $1 \%$ levels, respectively; p-values are in parentheses.

day, there may be a rise (decline) in precious metal ETF return in the current trading day and vice versa. At the $10 \%$ level significance, the precious metal ETF return had a positive relationship with the precious metal index return. While base metal ETFs exhibit positive bilateral relationships with their base metal indices at $1 \%$ level of significance, JJC showed a unilateral relationship. These findings might help investors or speculators reach a realized gain or hedge for risk from portfolio diversification. Likewise, the increase in one asset return creates a possible opportunity in investment. The exposure in precious metal ETFs and precious metal indices can be managed and controlled by investors. Therefore, the bilateral linkage revealed spillover effect in returns of among precious metal (base metal) ETFs and precious metal (base metal) prices, and was found through applying EGACRH-M-ARMA model. Positive bilateral relationships on these ETFs are in line with the findings of Chen [3] and Chen and Diaz 
[18].

\section{2) Spillover effect of volatility}

The volatility transmission between precious metal (base metal) ETFs and precious metal prices have been presented in this paper. Out of four precious metal ETFs, all estimated coefficients of lagged precious price returns were found to be positively significant at the $1 \%$ level on the volatilities of current precious metal ETFs. A one-way positive relationship between GLD and gold price index exhibited that lagged gold price has a strong positive effect on current gold ETF (GLD). This finding suggests that investors and traders have the sensitivity of gold ETF with the influence of the gold price. The lagged gold ETF did not have any effect on the current gold price, which means that gold is a distinct market. This evidence was also argued in the previous research of Batten et al. [21] on the distinctness of the precious metal market, and other studies on gold price, such as Sjaastad [22], Shafiee and Topal [23] and Wang and Chueh [24]. However, the positive significant volatility spillovers in a bidirectional way are evident during the period for SLV and PALL with silver and palladium price indices. This finding is consistent with the conclusion of Batten et al. [24] in the case of silver, while investigating the precious metal market.

For base metal ETFs, the significance of positive bilateral relationships is illustrated for three pairs of JJC, JJN, and JJT at the $10 \%$ level. The relationship between lead ETF (LD) return and lead price return represents the one-way relationship at the $1 \%$ level. The lagged lead ETF had a positive effect on the current lead price. This finding is in accordance with the study of Xiarchos and Fletcher [25] in terms of the copper market, while looking at the metal market. These results are evidence that precious metal (base metal) ETFs have an influence on the volatility of precious metal (base metal) market returns and vice versa. Thus, diligent trading of precious metal (base metal) ETF market may create strong active effects on the movement of market indices. These results are also in line with the conclusion of Chen and Huang [16] and Chen [3] on the bidirectional way in the volatility of ETFs. Investors and speculators can rely on these results to design optimal buying and selling strategies to increase the liquidity of their portfolio assets.

\section{3) Relationship between returns and risk}

Another advantage of examining spillover effects is that exploring the return or risk in precious metal (base metal) ETFs and precious metal (base metal) price indices can lead to an increase or decrease in each other through standard deviation. The finding in this research exhibits the contribution of the relationship between risk and return in daily ETFs and precious metal (base metal) markets with the positive correlation. This result is accordance with Morales and Bernadette [26] on the precious metal market, and Chen and Huang [16] and Chen and Diaz [18] on ETFs.

\section{Conclusions}

The spillover and leverage effects on returns and volatilities are captured by uti- 
lizing GARCH-M-ARMA and EGARCH-M-ARMA models between precious metal (base metal) ETFs and precious metal (base metal) prices. Based on the results, the significant positive effects of lagged precious metal (base metal) price returns on current precious metal (base metal) ETF returns and vice versa, were in accordance with previous research. Investors and fund managers can rely heavily on these findings to hedge and diversify their portfolios. The evidence of positive unilateral relationships in returns is represented by the SLV, PALL, and JJC, whereas other precious metal (base metal) performed bilateral positive relationship with current price returns.

Interestingly, the positive bi-directional way was detected for almost all precious metal (base metal) ETFs in volatilities, except GLD and LD. Moreover, the results can provide traders and speculators with a strong anticipation of concerned risks and returns in trading precious metal (base metal) ETFs. The positive relationship proved that return and risk gained in precious metal (base metal) ETFs could be derived from the increase (decrease) of the others. The recognition of spillover and leverage effects of precious metal (base metal) ETFs may provide investors, traders, speculators, and fund managers with an accurate investment instrument for making decisions. This finding can be utilized for policy implications regarding the spillover and the leverage effect through the hedge to properly evaluate volatility in terms of risk management in commodity ETFs. Referable to the data limitation of short span for about eight years, the timeline of precious metal series is limited which might provide insufficient results. Future study can extend the time period in order to receive more reliable solutions for bringing down the mixed results.

\section{References}

[1] Ackert, L.F. and Tian, Y.S. (2008) Arbitrage, Liquidity and the Valuation of Exchange Traded Funds. Financial Markets, Institutions and Instruments, 17, 331 362. https://doi.org/10.1111/j.1468-0416.2008.00144.x

[2] Charupat, N. and Miu, P. (2011) The Pricing and Performance of Leveraged Exchange-Traded Funds. Journal of Banking and Finance, 35, 966-977. https://doi.org/10.1016/j.jbankfin.2010.09.012

[3] Chen, J.H. (2011) The Spillover and Leverage Effects of Ethical Exchange Traded Fund. Applied Economics Letters, 18, 983-987. https://doi.org/10.1080/13504851.2010.520663

[4] Blitz, D. and Huij, J. (2012). Evaluating the Performance of Global Emerging Markets Equity Exchange-Traded Funds. Emerging Markets Review, 13, 149-158. https://doi.org/10.1016/j.ememar.2012.01.004

[5] Bollerslev, T., Chou, R. and Kroner, K. (1992) ARCH Modeling in Finance: A Selective Review of the Theory and Empirical Evidence. Journal of Econometrics, 52, 5 59. https://doi.org/10.1016/0304-4076(92)90064-X

[6] Bhar, R. and Nikolova, B. (2008) Return, Volatility Spillovers and Dynamic Correlation in the BRICEquity Markets: An Analysis Using a Bivariate EGARCH Framework. Global Finance Journal, 19, 203-218. https://doi.org/10.1016/j.gfj.2008.09.005

[7] Wei, K.C.J., Liu, Y.J., Yang, C.C. and Chaung, G.S. (1995) Volatility and Price 
Change Spillover Effects across the Developed and Emerging Markets. Pacific-Basin Finance Journal, 3, 113-136. https://doi.org/10.1016/0927-538X(94)00029-7

[8] Korkmaz, T., Çevik, E.I. and Atukeren, E. (2012) Return and Volatility Spillovers among CIVETS Stock Markets. Emerging Markets Review, 13, 230-252. https://doi.org/10.1016/j.ememar.2012.03.003

[9] Chan, K., Chan, K.C. and Karolyi, G.A. (1991) Intraday Volatility in the Stock Index and Stock Index Futures Markets. Review of Financial Studies, 4, 657-684. https://doi.org/10.1093/rfs/4.4.657

[10] Zhong, M., Darrat, A.F. and Otero, R. (2004) Price Discovery and Volatility Spillovers in Index Futures Markets: Some Evidence from Mexico. Journal of Banking and Finance, 28, 3037-3054. https://doi.org/10.1016/j.jbankfin.2004.05.001

[11] Kanas, A. (2000) Volatility Spillovers between Stock Returns and Exchange Rate Changes: International Evidence. Journal of Business Finance and Accounting, 27, 447-467. https://doi.org/10.1111/1468-5957.00320

[12] Zhang, Y.J., Fan, Y., Tsai, H.T. and Wei, Y.M. (2008) Spillover Effect of US Dollar Exchange Rate on Oil Prices. Journal of Policy Modeling, 30, 973-991.

https://doi.org/10.1016/j.jpolmod.2008.02.002

[13] Kim, B.S. (2011) Linkages between the U.S. and Asia-Pacific Exchange Traded Funds (ETF) Markets: Evidence from the 2007-2008 Global Financial Crises. Asian Academy of Management Journal of Accounting and Finance, 7, 53-72.

[14] Krause, T. and Tse, Y. (2013) Volatility and Return Spillovers in Canadian and U.S. Industry ETFs. International Review of Economics and Finance, 25, 244-259. https://doi.org/10.1016/j.iref.2012.07.009

[15] Curcio, R.J., Anderson, R.I., Guirguis, H. and Boney, V. (2012) Have Leveraged and Traditional ETFs Impacted the Volatility of Real Estate Stock Prices? Applied Financial Economics, 22, 709-722. https://doi.org/10.1080/09603107.2011.624080

[16] Chen, J.H. and Huang, C.Y. (2008) An Analysis of the Spillover Effects of Exchange-Traded Funds. Applied Economics, 42, 1155-1168. https://doi.org/10.1080/00036840701721182

[17] Nelson, D.N. (1991) Conditional Heterokedasticity in Asset Returns: A New Approach. Econometrica, 59, 347-370. https://doi.org/10.2307/2938260

[18] Chen, J.H. and Diaz, J.F. (2012) Spillover and Leverage Effects of Faith-Based Exchange-Traded Funds. Journal of Business and Policy Research, 7, 1-12.

[19] Chou, R.Y. (1988) Volatility Persistence and Stock Valuations: Some Empirical Evidence Using GARCH. Journal of Applied Econometrics, 3, 279-294. https://doi.org/10.1002/jae.3950030404

[20] Lanne, M. and Saikkonen, P. (2004) A Skewed GARCH-in-mean Model: An Application to US Stock Returns. University of Jyväskylä, Jyväskylä.

[21] Batten, J.A., Ciner, C. and Lucey, B.M. (2010) The Macroeconomic Determinants of Volatility in Precious Metals Markets. Resources Policy, 35, 65-71. https://doi.org/10.1016/j.resourpol.2009.12.002

[22] Sjaastad, L.A. (2008) The Price of Gold and the Exchange Rates: Once Again. Resources Policy, 33, 118-124. https://doi.org/10.1016/j.resourpol.2007.10.002

[23] Shafiee, S. and Topal, E. (2010) An Overview of Global Gold Market and Gold Price Forecasting. Resources Policy, 35, 178-189. https://doi.org/10.1016/j.resourpol.2010.05.004

[24] Wang, Y.S. and Chueh, Y.L. (2013) Dynamic Transmission Effects between the Interest Rate, the US Dollar, and Gold, and Crude Oil Prices. Economic Modelling, 
30, 792-798. https://doi.org/10.1016/j.econmod.2012.09.052

[25] Xiarchos, I.M., and Fletcher, J.J. (2009) Price and Volatility Transmission between Primary and Scrap Metal Markets. Resources, Conservation and Recycling, 53, 664673. https://doi.org/10.1016/j.resconrec.2009.04.020

[26] Morales, L. and Bernadette, A.O. (2011) Comparative Analysis on the Effects of the Asian and Global Financial Crises on Precious Metal Markets. Research in International Business and Finance, 25, 203-227. https://doi.org/10.1016/j.ribaf.2011.01.004 